\title{
Kreativitas pada pelukis di Bali
}

\author{
A. A. Gd Gita Galah Gumilang dan Yohanes K. Herdiyanto \\ Program Studi Psikologi, Fakultas Kedokteran, Universitas Udayana \\ herdiyanto@unud.ac.id
}

\begin{abstract}
Abstrak
Bali sebagai salah satu destinasi pariwisata terbaik di dunia menawarkan beragam keindahan alam dan budayanya. Pariwisata Bali yang berkembang pesat membuat adanya lapangan kerja untuk para seniman dengan menjual jasa pada wisatawan yang datang ke Bali, khususnya pelukis. Pelukis memiliki kecenderungan untuk berkarya tanpa adanya batasan tertentu, namun dengan menjadikan melukis sebagai profesi, mengharuskan pelukis untuk menuruti permintaan pemesan maupun tren lukisan yang laku di pasaran, hal ini tentu berdampak dengan kreativitas yang dimiliki oleh pelukis. Tujuan penelitian ini adalah untuk mengetahui kreativitas pada pelukis di Bali. Penelitian ini menggunakan metode penelitian kualitatif dengan pendekatan fenomenologi yang tergabung dalam penelitian payung dengan tema "proses kreatif pada seniman di Bali" yang diinisiasi oleh Program Studi Psikologi, Fakultas Kedokteran, Universitas Udayana. Peneliti menggunakan 7 responden laki-laki berusia 20 hingga 60 tahun yang berdomisili di Bali dan mempunyai profesi sebagai pelukis. Hasil penelitian yang didapatkan adalah faktor penghambat dan pendukung kreativitas secara internal maupun eksternal. Pelukis mengembangkan kreativitas melalui proses merenung, pengamatan hingga mengubah stres untuk menjadi sumber inspirasi, serta adanya pengaruh pariwisata terhadap kreativitas.
\end{abstract}

Kata kunci: Kreativitas, pariwisata Bali, pelukis.

\begin{abstract}
Bali as one of the world's best tourism destination offers a variety of natural beauty and culture. Tourism in Bali have a rapid development which makes the existence of employment for artists by selling services to tourists who come to Bali, especially painter. Painter have a tendency to work without a certain limit, but by making painting as a profession, requires painter to comply with requests from buyers and painting trends, this certainly has an impact with the creativity that is owned by the painter. The purpose of this study is to determine the dynamics of creativity of painter in Bali. This research uses qualitative research method with phenomenology approach which is incorporated in grand research with theme "creative process on artist in Bali" initiated by Psychology Study Program, Faculty of Medicine, University of Udayana. Researcher use 7 male respondents who can be classified as individuals with age $20-60$ years, were domiciled in Bali and have a profession as a painter. The results obtained are the inhibiting factors and creativity supporters internally and externally. The painter gets the idea through the process of contemplation, observation to change stress to be a source of inspiration, and the influence of tourism on creativity.
\end{abstract}

Keywords: Bali's tourism, creativity, painter. 


\section{KREATIVITAS PADA PELUKIS DI BALI}

\section{LATAR BELAKANG}

Bali merupakan salah satu dari 35 provinsi di Indonesia yang menjadi tujuan wisata terbaik yang dimiliki Indonesia. Nursastri (2017) mengemukakan bahwa penghargaan diberikan oleh situs TripAdvisor lewat Travellers' Choice Awards 2017, yang menjadikan Bali sebagai tujuan wisata nomer 1 di dunia, diikuti oleh London di peringkat ke-2 lalu Paris di peringkat ke3. Bali sebagai destinasi wisata selain menawarkan keindahan alamnya, juga memiliki keunikan budaya sebagai daya tarik wisata (Bagus, 2016), budaya yang lahir tentu tidak lepas dari peran penduduk lokal di Bali yang membentuk kebudayaan, seperti yang diungkapkan Budiwiyanto (2016) bahwa kebudayaan Indonesia tidak lepas dari peran penduduk atau disebut dengan local genius.

Berdasarkan data dari Badan Statistik Provinsi Bali (2018), total penduduk Bali berjumlah 3.890 .757 jiwa dengan 3.247.283 penduduk memeluk agama Hindu, ini membuat Bali menjadi salah satu provinsi di Indonesia yang memiliki penduduk pemeluk agama Hindu, hal tersebut tentu berpengaruh dalam kehidupan sehari-hari masyarakat Bali yang hampir seluruh aspek kehidupan masyarakat Bali mengandung unsur ataupun nilai-nilai keagamaan yang melahirkan berbagai macam budaya dan kesenian. Adapun jenis-jenis kesenian yang terdapat di Bali yaitu, seni ukir, seni tari, seni musik (gamelan) dan seni lukis.

Seni ukir di aplikasikan pada arsitektur rumah, yaitu pada gapura candi bentar (bangunan yang terdiri dari dua candi yang memiliki bentuk identik dan diletakkan sejajar sebagai jalan utama untuk masuk menuju halaman rumah) yang berhiaskan ukiran-ukiran khas atau bisa juga ditemukan pada tempat ibadah (Pura) umat Hindu yang hampir seluruh sudut bangunan berhiaskan ukiran-ukiran ataupun berupa patung-patung yang terdapat pada beberapa sudut bangunan Pura. Terdapat lima jenis ukiran Bali, yaitu ukiran pepatran, kekarangan, keketusan, ukiran patung dan relief. Ukiran pepatran yaitu ukiran yang bermotifkan dedaunan atau bunga-bungaan. Lalu jenis ukiran kekarangan yang berupa binatang-binatang, yang pada umumnya menonjolkan bentuk kepala binantang. Setelah itu terdapat jenis ukiran keketusan, merupakan ukiran yang berbentuk bagian dari tumbuhan dan dibuat berulang-ulang atau berpola. Terdapat pula jenis ukiran patung yang berbentuk manusia atau pewayangan. Lalu yang terakhir adalah ukiran relief, yaitu jenis ukiran yang timbul dan biasanya mengandung kisah atau cerita (Artadi, 2010).

Seni tari yang terbagi menjadi tiga kategori, yaitu tari wali atau tarian sakral yang dipentaskan di halaman bagian dalam Pura, tari bebali atau jenis tarian upacara yang biasanya dipertunjukan pada halaman tengah Pura yang bersifat sakral atau hiburan, dan yang terakhir adalah jenis tari balih-balihan, yaitu jenis tarian yang bersifat hiburan yang biasa dipentaskan diluar atau di halaman depan pura (Iryanti, 2000).

Seni musik juga tidak lepas dari kehidupan masyarakat Bali yang mempunyai alat musik tradisional disebut dengan gamelan. Gamelan di Bali berfungsi untuk mengiringi kegiatankegiatan keagamaan seperti mengiringi tarian yang di pentaskan saat menjalani upacara agama, ataupun bisa juga dipentaskan untuk kepentingan hiburan. Gamelan Bali dapat dibagi menjadi tiga kelompok besar menurut zamannya, diantaranya adalah gamelan wayah, gamelan madya dan gamelan anyar (Suliartini, 2014).

Pelukis di Bali pada jaman dahulu tidak melukis untuk dijual, melainkan hanya dipergunakan untuk keperluan upacara keagamaan ataupun untuk hiasan di istana kerajaan. Jenis lukisan yang biasa dibuat oleh pelukis sebelum masuknya aliran modern adalah lukisan Kamasan. Yaitu jenis aliran lukisan yang terinspirasi dari kisah pewayangan dengan menggunakan teknik mewarnai menggunakan warna alam yang dicampur dengan perekat (Yudiarta, 2016).

Seni lukis juga diaplikasikan pada pembuatan wayang. Seni lukis wayang berkembang di mulai di Desa Kamasan, Kabupaten Klungkung Bali sekitar abad 15 dan mencapai masa kejayaan pada pemerintahan Dalem Waturenggong yang kemudian menyebarluaskan gaya Kamasan ke seluruh wilayah Bali. Sebagai Pusat kekuasaan, kerajaan Klungkung membuat bangunan monumental yang masih ada sampai saat ini yaitu bangunan gedung Kertha Gosa yang terdapat di kabupaten Klungkung, tempat tersebut merupakan tempat penghakiman/pengadilan dan rapat umum dengan menghadirkan mural wayang kamasan di langit-langit atap dengan berbagai cerita legendaris (Mudana, 2015).

Budaya luar yang masuk melalui turis asing juga memengaruhi perkembangan seni lukis di Bali, khususnya melalui tokohtokoh pelukis asing yang masuk memengaruhi bagaimana pelukis tradisional Bali mengembangkan kreativitasnya melalui aliran-aliran lukis baru, salah satunya adalah Don Antonio Blanco, seorang pelukis kelahiran Filipina yang sampai di Bali pada tahun 1952 lalu menikahi perempuan Bali dan akhirnya memutuskan untuk menetap di Ubud, Gianyar. Antonio Blanco memiliki karakter atau aliran lukisan yang secara khusus menunjukan keindahan tubuh perempuan Bali. Selain itu ada pula tokoh pelukis lain seperti Antonia Blanco yang berasal dari luar Indonesia seperti Adrien Jean Le Mayeur, yang datang ke Singaraja pada tahun 1932 dan memutuskan untuk menetap di Denpasar, juga memiliki pengaruh melalui lukisan-lukisan pemandangan dengan menggunakan cat air atau acrylic. Selain itu terdapat pula tokoh-tokoh lain, sebut saja Jose Miguel Covarrubias yang datang ke Bali pada tahun 1933 yang menganut aliran illustrasi dan karikatur atau kartunis. Ada pula Walter Spies yang datang dan memutuskan untuk menetap di Bali pada tahun 1923, memiliki aliran naturalis dengan melukis pemandangan-pemandangan dan kehidupan tradisonal Bali. Selain itu terdapat pula pelukis asal Belanda bernama Rudolf Bonnet yang bahkan membangun rumah sekaligus dijadikan studio lukisan di Campuhan, Ubud, yang berisikan lukisan dengan aliran ekspresif yang kini di bangun menjadi Museum Puri Lukisan (Azhar, 2017).

Seni lukis yang pada mulanya hanya memiliki aliran tradisional kini telah berembang dengan masuknya beberapa aliran lukis lainnya seiring dengan era globalisasi dan pengaruh dari pelukis-pelukis mancanegara yang memutuskan untuk menetap di Bali. Hal ini membuat banyak hal baru yang dapat 
dipelajari oleh pelukis yang terdapat di Bali yang juga membedakan dari seni lain yang terdapat di Bali, karena tidak seperti seni tari ataupun ukir yang sudah memiliki dasar atau pakem dari budaya setempat yang ada untuk dikomersilkan. Pelukis di Bali tidak jarang mendapatkan pesanan lukisan diluar dari lukisan dengan aliran lukisan tradisional. Pelukis pada umumnya juga menganut aliran tertentu yang paling disukai atau di kuasai, namun dengan berkembanya pariwisata serta adanya permintaan, sering kali aliran yang dianut oleh pelukis berbenturan dengan pesanan ataupun tren lukisan yang sedang laku terjual di pasaran. Hal tersebut terjadi dikarenakan adanya transformasi pada kesenian Bali, khususnya pada seni rupa atau seni lukis. Seni rupa atau seni lukis di Bali kini dikomersilkan seiring berkembangnya pariwisata sesuai dengan selera dan pandangan wisatawan yang datang ke Bali (Diah, 2010).

Pergeseran pada kesenian yang pada mulanya hanya bertujuan untuk kegiatan keagamaan ataupun hiburan untuk masyarakat Bali sendiri, kini beralih fungsi menjadi jasa yang ditawarkan ke wisatawan yang datang, seperti beberapa tarian dan gamelan yang kini dipentaskan hanya untuk hiburan, produk seni seperti patung, wayang ataupun lukisan yang kini dikomersilkan untuk tujuan wisata serta penghidupan bagi seniman pembuatnya, seperti yang dinyatakan oleh Himawan (2016), bahwa terjadi perubahan dalam budaya dan kesenian Bali yang dikarenakan oleh perkembangan pariwisata yang terjadi di Bali memang betul adanya. Kesenian yang terpengaruh salah satunya adalah seni lukis. Para seniman atau pelukis Bali kini harus menghadapi era globalisasi seiring berkembangnya pariwisata yang ada di Bali ditambah dengan tuntutan untuk memenuhi kebutuhan sehari-hari. Sehingga tidak jarang pelukis Bali kini harus mengorbankan keinginan diri untuk melukis sesuai aliran yang diminati demi mengikuti tren pasar yang ada.

Urbanus dan Febianti (2017) menyebutkan bahwa pariwisata Bali memberi dampak terhadap kehidupan masyarakat Bali, baik dampak positif maupun negatif. Dampak positif yang diberikan oleh perkembangan pariwisata Bali adalah terbukanya lapangan kerja untuk masyarakat, sedangkan dampak negatif yang diakibatan oleh perkembangan pariwisata Bali adalah berubahnya pola masyarakat Bali yang lebih ekonomis, sehingga perlahan-lahan menggeser nilai-nilai budaya Bali untuk kepentingan ekonomi dan pariwisata. Pembuatan karya seni, khususnya lukisan tentu membutuhkan kreativitas. Kreativitas dalam kamus Besar Bahasa Indonesia adalah kemampuan individu dalam menciptakan sesuatu yang baru baik dalam bentuk gagasan ataupun karya nyata. Runco dan Pritzker (1999) menyatakan yang memengaruhi kreativitas individu adalah berasal dari interaksi antara lingkungan sosial - kondisi psikologis - kondisi fisik individu.. Untuk itu peneliti ingin mengetahui bagaimana kreativitas yang dimiliki oleh pelukis yang ada di Bali serta bagaimana pengaruh pariwisata Bali memengaruhi kreativitas pelukis. Rhodes (dalam Munandar, 2009) menyatakan bahwa pada umumnya kreativitas dirumuskan dalam istilah pribadi (person), proses (process), produk (product) dan dorongan (press) individu ke perilaku kreatif. Csikszentmihalyi juga menyebutkan bahwa faktor pendukung kreativitas individu untuk muncul adalah predisposisi genetis (genetic predisposition), dalam arti individu yang memiliki system sensori peka terhadap warna dan cahaya akan lebih mudah mengembangkan bakat untuk menjadi pelukis (Runco \& Pritzker, 1999). Berdasarkan pendekatan yang telah dilakukan, penelitian ini bertujuan untuk menggali mengenai kreativitas dan bagaimana pengaruh pariwisata terhadap kreativitas pada pelukis di Bali.

\section{METODE PENELITIAN}

Pendekatan yang digunakan dalam penelitian ini yaitu pendekatan fenomenologi agar peneliti mendapatkan penjelasan dari sebuah fenomena yang terjadi dan dialami responden (Ghony \& Almanshur, 2012). Oleh sebab itu peneliti ingin memahami dan mempelajari berdasarkan sudut pandang individu yang mengalami langsung fenomena yang terjadi serta bagaimana pengaruh bagi individu tersebut. Maka dari itu dengan menggunakan pendekatan fenomenologi, diharapkan dapat mengetahui apa saja faktor yang memengaruhi kreativitas pada pelukis di Bali serta bagaimana individu bersikap terhadap fenomena yang ada.

\section{Kriteria Responden}

Penelitian ini melibatkan 7 orang pelukis laki-laki. Faktor pertimbangan dalam memilih responden penelitian ini adalah faktor geografis, faktor pendidikan dan faktor usia. Berdasarkan faktor geografis, subjek penelitian adalah pelukis yang berdomisili di Bali guna mendapatkan tujuan penelitian mengenai bagaimana pengaruh pariwisata terhadap kreativitas pelukis. Responden uga dipiih berdasarkan faktor pendidikan, guna medapatkan data yang lebih beragam dari individu yang belajar melukis secara formal dan otodidak. Faktor usia responden dengan kisaran 20 tahun hingga 60 tahun juga diharapkan untuk memberikan data yang beragam melalui sudut pandang yang berbeda.

\section{Tempat Penelitian}

Tempat yang digunakan untuk penelitian adalah sekitaran Sanur, Denpasar, Seminyak dan Tegalalang, Gianyar. Dilaksanakan dari bulan November hingga Desember 2017. Tempat yang digunakan dalam mengambil data dalam peneitian merupakan kawasan pariwisata yang ada di Bali yang juga menjadi tempat tinggal dari tiap responden yang dimintai keterangan guna mendapatkan data yang akan menjawab pertanyaan dari penelitian.

\section{Teknik Pengambilan Data}

Teknik dalam pengambilan data dilakukan dengan observasi dan wawancara secara semi terstruktur. Obeservasi dilakukan guna memperoleh informasi atau data yang akan berguna dalam penelitian. Peran peneliti dalam observasi menggunakan pendekatan partisipan sebagai pengamat, yaitu obersver atau pengamat tidak sepenuhnya bergabung dalam individu atau kelompok yang diamati (Moleong, 2013).

Teknik wawancara yang digunakan adalah wawancara semi terstruktur, yaitu wawancara yang tetap menggunakan guideline (panduan) wawancara, namun tidak menutup kemungkinan untuk mengembangkan pertanyaan untuk mendapatkan informasi yang lebih luas (Sugiyono, 2010). 


\section{Teknik Triangulasi Data}

Ahmadi (2014), menjabarkan triangulasi menjadi empat model yaitu, triangulasi data, triangulasi teori, triangulasi investigator/peneliti dan triangulasi metodologis. Pada penelitian ini menggunakan model triangulasi data dan triangulasi investigator/ peneliti.

\section{Etika-etika Penelitian}

Agar penelitian ini berjalan dengan baik dan tidak merugikan pihak manapun, maka peneliti melakukan langkah-langah sebagai berikut:

1. Memberikan informed consent kepada responden baik secara lisan maupun secara tertulis.

2. Peneliti menjelaskan mengenai tujuan penelitian, dan prosedur, antisipasi dari keikutsertaan yang bila diketahui mungkin dapat memengaruhi ketersediaan untuk berpartisipasi bagi responden.

3. Responden memiliki hak untuk menarik diri dari keikutertaan dan megundurkan diri dari penelitian setelah penelitian dimulai, konsekuensi yang mungkin timbul dari penarikan dan pengunduran diri adalah keterbatasan kerahasiaan, intensif untuk responden dan siapa yang dapat dihubungi untuk memperoleh informasi lebih lanjut.

4. Jika responden tidak dapat membuat persetujuan karena keterbatasan atau kondisi khusus, maka peneliti melakukan upaya memberikan penjelasan dan mendapatkan persetujuan dari pihak berwenang yang mewakili responden atatu melakukan upaya lain seperti diatur oleh aturan yang berlaku.

5. Peneliti berusaha menghindari penggunaan segala bentuk pemaksaan termasuk daya tarik yang berlebihan agar responden ikut serta dalam penelitian.

6. Peneliti sebelum merekam suara atau gambar untuk pengumpulan data harus memperoleh izin secara tertulis dari responden, namun persetujuan tidak diperlukan apabila perekaman murni untuk kepentingan observasi di tempat umum dan diantisipasi tidak akan berakibat negatif atatu terancamnya kesejahteraan atau keselamatan responden.

Peneliti tidak harus meminta persetujuan responden apabila penelitian melibatkan individu secara anonym atau tidak melibatkan secara pribadi dan diasumsikan tidak ada risiko gangguan pada kesejahteraan atau keselamatan yang mungkin timbul pada responden atatu pihak-pihak terkait (HIMPSI, 2010).

\section{HASIL PENELITIAN}

Berdasarkan data yang sudah di analisa, peneliti menyimpulkan faktor kreativitas pada pelukis di Bali dapat dibagi menjadi faktor internal dan faktor eksternal, kedua jenis faktor tersebut dapat dibedakan lagi menjadi faktor pendukung ataupun penghambat dalam kreativitas. Faktor-faktor dapat menjadi penghambat ataupun pendukung, seperti faktor mood dan rasa kurang puas pada momen tertentu dapat menjadi pendukung pelukis dalam berkreativitas, namun di saat tertentu dapat juga menjadi faktor penghambat.
Faktor mood dapat menjadi pendukung apabila mood yang dirasakan oleh pelukis cukup baik, hingga pelukis mendapatkan gairah untuk membuat atau menyelesaikan lukisan. Namun apabila mood yang dirasakan jelek atau tidak baik, justru dapat membuat pelukis menjadi malas dan merasa tidak ingin untuk membuat lukisan sama sekali. Faktor rasa kurang puas juga dapat menjadi pendukung maupun penghambat dalam kreativitas yang dimiliki oleh pelukis, dikarenakan pada momen tertentu rasa kurang puas dapat memicu pelukis untuk terus berkreasi terhadap lukisan yang dibuat hingga proses kreatif terus berlangsung namun juga dapat menjadi penghambat karena pelukis selalu merasa lukisan yang dikerjakan tidak pernah selesai. Hasil dari faktor pendukung maupung penghambat secara internal dapat dilihat pada tabel berikut (terlampir).

Faktor eksternal yang memengaruhi kreativitas juga dapat dibagi menjadi faktor pendukung dan penghambat. Faktorfaktor yang dapat digolongkan sebgai pendukung maupun penghambat pada momen tertentu meliputi faktor lingkungan baik secara fisik, sosial ataupun keluarga. Faktor permintaan pasar yang dapat mendukung kreativitas pelukis untuk berkembang namun juga menjadi penghambat apabila permintaan pasar yang justru membatasi kreativitas dari pelukis. Faktor eksternal kreativitas dapat dilihat pada table berikut (terlampir).

Proses kreativitas yang dimiliki pelukis di Bali berdasarkan data-data verbatim yang diperoleh dapat disimpulkan bahwa pelukis dalam melakukan proses kreatif digerakkan oleh adanya Ide dan inspirasi yang didapatkan cenderung berasal dari kegelisahan atau stres yang dialami oleh pelukis itu sendiri. Sumber kegelisahan atau stres yang dialami berasal dari beragam sumber, mulai dari lingkungan keluarga, permasalahan dalam lingkungan sosial atau lingkungan fisik. Ide atau inspirasi dapat ditemukan oleh pelukis melalui pengamatan terhadap alam maupun fenomena lingkungan, atau bisa juga dari proses merenung yang dilakukan hingga mendapatkan ide untuk melukis.

Berdasarkan penjelasan tersebut maka dapat dijabarkan dengan bagan sebagai berikut (terlampir).

Bali sebagai daerah pariwisata selain memberikan pengaruh dari budaya dan aliran seni tradisional, juga berpengaruh dengan kedatangan turis yang datang, sehingga terdapat permintaan pasar yang juga menjadi lahan pencaharian bagi pelukis di Bali. Pesanan yang didapat biasanya memberikan batasan waktu dalam pengerjaan dan juga batasan tema sesuai keinginan dari pembeli, yang juga berpengaruh kepada proses kreativitas dalam pengerjaan lukisan tersebut. Pesanan dapat berdampak positif juga negatif bagi pelukis yang ada di Bali. Di satu sisi pelukis dapat menjual hasil-hasil karya mereka ke pasaran yang ada di Bali dan dapat menjadikan melukis sebagai profesi untuk memenuhi kebutuhan hidup sehari-hari. Lukisan yang bukan pesanan ataupun pesanan apabila mendapatkan komentar, baik komentar positif atau negatif akan tetap diterima sebagai masukan bagi pelukis. Berdasarkan penjelasan tersebut maka dapat dijabarkan dengan bagan sebagai berikut (terlampir). 


\section{DAFTAR PUSTAKA}

\section{PEMBAHASAN DAN KESIMPULAN}

Teori empat $\mathrm{P}$, person (pribadi), press (dorongan), process (proses) dan product (produk) dari Rhodes (dalam Munandar, 2009) maka dapat dijelaskan sebagai berikut, person (pribadi), yaitu merujuk kepada individu atau pelukis itu sendiri yang memiliki kemampuan lebih dalam bidang tertentu, dalam hal nii khsususnya pada bidang seni lukis dan memiliki keinginan untuk terus berkarya dan mengembangkan kemampuan dalam melukis. Process (proses), yaitu adanya proses didalam berkreativitas, yang bermula dapat dari inspirasi murni dari pelukis ataupun dari orang lain (pemesan lukisan) hingga diterjemahkan keatas kanvas. Press (dorongan), dorongan yang dapat berasal dari dalam maupun luar individu, dorongan dapat berupa ide atau inspirasi sehingga muncul keinginan untuk berkarya. Ide yang mucul dapat berasal dari stres, hasil perenungan ataupun dengan pengamatan alam dan objek sekitar. Product (produk), yaitu mampu menciptakan sebuah karya baru yang belum pernah diciptakan sebelumnya. Dalam konteks pelukis di Bali yaitu, kemampuan pelukis untuk menciptakan lukisan menggunakan gaya atau aliran khas dari pelukis itu sendiri.

Csikzentmihalyi (Runco \& Pritzker, 1999) juga mengungkapkan bahwa orang kreatif memiliki kemampuan luar biasa dalam menyesuaikan diri terhadap hampir setiap situasi dan melakukan apa yang diperlukan untuk mencapai tujuan yang diinginkan. Hal ini tercermin pada pelukis yang enjadikan segala masalah ataupun stres yang dimiliki untuk menjadi sebuah sumber ide dengan tujuan dasar untuk tetap dapat berkarya.

Proses kreativitas pada pelukis di Bali digerakan oleh ide yang bersumber dari proses perenungan, stres, atau pengamatan objek dan alam. Stres dapat bermula dari permasalahan sosial, keluarga ataupun lingkungan fisik, namun stres tersebut diterjemahkan menjadi ide untuk dituangkan dalam proses melukis. Pariwisata di Bali mendatangkan peluang bagi seniman untuk menjual hasil karya seni, adanya lukisan yang dikerjakan berdasarkan pesanan dan bukan pesanan juga berpengaruh terhadap kreativitas pelukis di Bali. Lukisan yang dibuat melalui pesanan, pelukis tidak jarang terbentur dengan permintaan pemesan mengenai tema yang tidak sesuai dengan aliran yang diseukai atau diminati oleh pelukis demi mengikuti permintaan pemesan atau permintaan pasar.

Penelitian serupa untuk selanjutnya disarankan untuk menambah jumlah responden tanpa batasan jenis kelamin hingga mendapatkan sumber data yang lebih beragam, sehingga diharapkan mendapatkan hasil yang lebih luas dan beragam.
Artadi, P. 2010. Keketusan,pepatraan dan kekarangan. Di unduh dari http://www.isi-dps.ac.id/berita/keketusan-pepatraan-dankekarangan/.

Azhar, R. (2017). Enam pelukis Asing yang membuat Bali menjadi daya tarik dunia. $\mathrm{Di}$ unduh dari https://www.divertone.com/enam-pelukis-asing-yangmembuat-bali-jadi-daya-tarik-dunia/.

Badan Pusat Statistik Bali. (2018). Di unduh dari https://bali.bps.go.id/statictable/2018/02/15/33/pendudukprovinsi-bali-menurut-agama-yang-dianut-hasil-sensuspenduduk-2010.html.

Bagus, R.U. (2016). Daya tarik pariwisata Bali. Di unduh dari https://www.posbali.id/daya-tarik-pariwisata-bali/.

Budiwiyanto, J. (2016). Tinjauan tentang perkembangan pengaruh local genius dalam seni bangunan sakral (keagamaan) di Indonesia. Ornamen, 2(1).

Diah, P., \& Pitanatri, S. (2010) Komodifikasi seni lukis Bali sebagai skibat sariwisata: Perspektif Akulturasi budaya terhadap aspek sosio kultural masyarakat Bali. Di unduh dari http://www.academia.edu/13821023/.

Febianti, F., \& Urbanus, N. (2017). Analisis dampak perkembangan pariwisata terhadap perilaku konsumtif masyarakat wilayah Bali selatan. Jurnal Kepariwisataan dan Hospitalitas, 1(2), 118-133.

Ghony, M.A., \& Almanshur, F. (2012). Metodologi penelitian kualitatif. Jogjakarta: Ar-Ruzz Media.

Himawan, W., Sabana \& A. Rikrik K. (2016). Pengaruh pariwisata pada keberagaman seni rupa sebagai modal kultural Bali: Studi pada komunitas dan perhelatan seni rupa di wilayah Denpasar, Klungkung dan Singaraja. Di unduh dari http://journal.isi.ac.id/index.php/JOUSA/article/view/1478.

Himpunan Psikologi Indonesia. (2010). Kode etik psikologi Indonesia. Jakarta: Pengurus Pusat Himpunan Psikologi Indonesia.

Iryanti, V. Eny (2000). Tari Bali: Sebuah telaah historis (Bali Dance : A Historical Research). Harmonia: Jurnal Pengetahuan Dan Pemikiran Seni, 82-86.

Moleong, L. J. (2013). Metode penelitian kualitatif. Edisi revisi. Bandung: PT.Remaja Rosdakarya.

Mudana, I. W. (2015). Transformasi seni lukis wayang kamasan pada era postmodern di Klungkung, Bali. (Doctoral dissertation) Universitas Udayana.

Munandar,Utami.(2009). Pengembangan kreativitas anak berbakat.Jakarta:Rineka cipta.

Nursastri, S.A. (2017). Bali dinobatkan sebagai destinasi wisata terbaik di dunia. Di unduh dari https://travel.kompas.com/read/2017/04/14/200540027/bali. dinobatkan.sebagai.destinasi.wisata.terbaik.di.dunia./.

Runco, M. A. \& Pritzker S. R. (1999). Encyclopedia Of Creativity. Fullerton, California: California State Of University.

Sugiyono. (2010). Metode penelitian pendidikan pendekatan kuantitatif, kualitatif, dan R\&D. Bandung: Alfabeta.

Suliartini, M. (2014). Fungsi, jenis dan bentuk gamelan di Bali. Di unduh dari http://madesuliartini.blogspot.co.id/2014/01/.

Yudiarta, I Nyoman. (2016). Seni dan budaya Bali: Perkembangan seni lukis Bali. $\mathrm{Di}$ unduh dari http://sanggingbrus.blogspot.co.id/2016/11/perkembanganseni-lukis-di-bali.html/. 
A.A.G.G.G GUMILANG \& Y.K HERDIYANTO

\section{LAMPIRAN}

Tabel 1

Faktor internal kreativitas

\begin{tabular}{|c|c|c|}
\hline Faktor kreativitas & Pendukung & Penghambat \\
\hline 1. Falsor Keturuna & $\frac{\text { Ketunuan: memiliki orang tua atau berasal dasi keluarga }}{\text { seai }}$ & - \\
\hline 2. Pengembangan diì & $\begin{array}{l}\text { Latihan: berlatih berlatih tiap hari, mengikuti kompetisi, } \\
\text { bersaing dengan pelukis laia }\end{array}$ & - \\
\hline 3. Ketertarikan pribadi & $\begin{array}{l}\text { Minat: memeiliki mianat pada aliran lukisan tertentu, ada } \\
\text { keinginan untuk mengasah kemampuan }\end{array}$ & - \\
\hline 4. Mood & $\begin{array}{l}\text { Mood suasana hati respooden yang baik dapat } \\
\text { meningkatkan motivasi untak mengerjakan suatu karya } \\
\text { lukisan dengan baik }\end{array}$ & $\begin{array}{l}\text { Mood: apabila mood responden kurang baik, dapat } \\
\text { memengaulai keinginan untuk berkarya } \\
\text { menyelesaikan lukisan }\end{array}$ \\
\hline 5. Stres & $\begin{array}{l}\text { Stres: kegelisahan yang justru menginspirasi responden } \\
\text { untuk menuangkan hal tersebut menjadi karya seni } \\
\text { lukisan }\end{array}$ & - \\
\hline 6. Melakuka kegiatan lain & $\begin{array}{l}\text { Rosfresking melakukan kegiatan diluar melukis dapat } \\
\text { menyegarkan pikira dan mengatasi kejenuhan } \\
\text { resposden dalan mengerjakan lukisan }\end{array}$ & - \\
\hline 7. Rasa kurang puas & $\begin{array}{l}\text { Kepuasan: adanya keinginan untuk selalu menambahkan } \\
\text { sesuatu pada lukisan untuk meajadi lehì baik dari } \\
\text { sebelumnya sehingga dapat meningkatkan kaalitas } \\
\text { lukisan }\end{array}$ & $\begin{array}{l}\text { Kepuasan: selalu merasa lukisan yang dibuat belum } \\
\text { selesai, sehingga tidak pernà merasa benar-benar } \\
\text { puas deaga lukisan yang tela hibuat }\end{array}$ \\
\hline 8. Mamajensen waktu & - & $\begin{array}{l}\text { Desdlinte: adazya batasan waktu sententu dalam } \\
\text { penyelesaian lukisan membeat responden } \\
\text { meayelesaikan lukisan tidak sesai dengan } \\
\text { keinginan sendiri yang berakibat penyelesaian } \\
\text { lukisan dibuat secana tergesa-gesa atau kurang } \\
\text { maksimal }\end{array}$ \\
\hline
\end{tabular}


Tabel 2

Faktor eksternal kreativitas

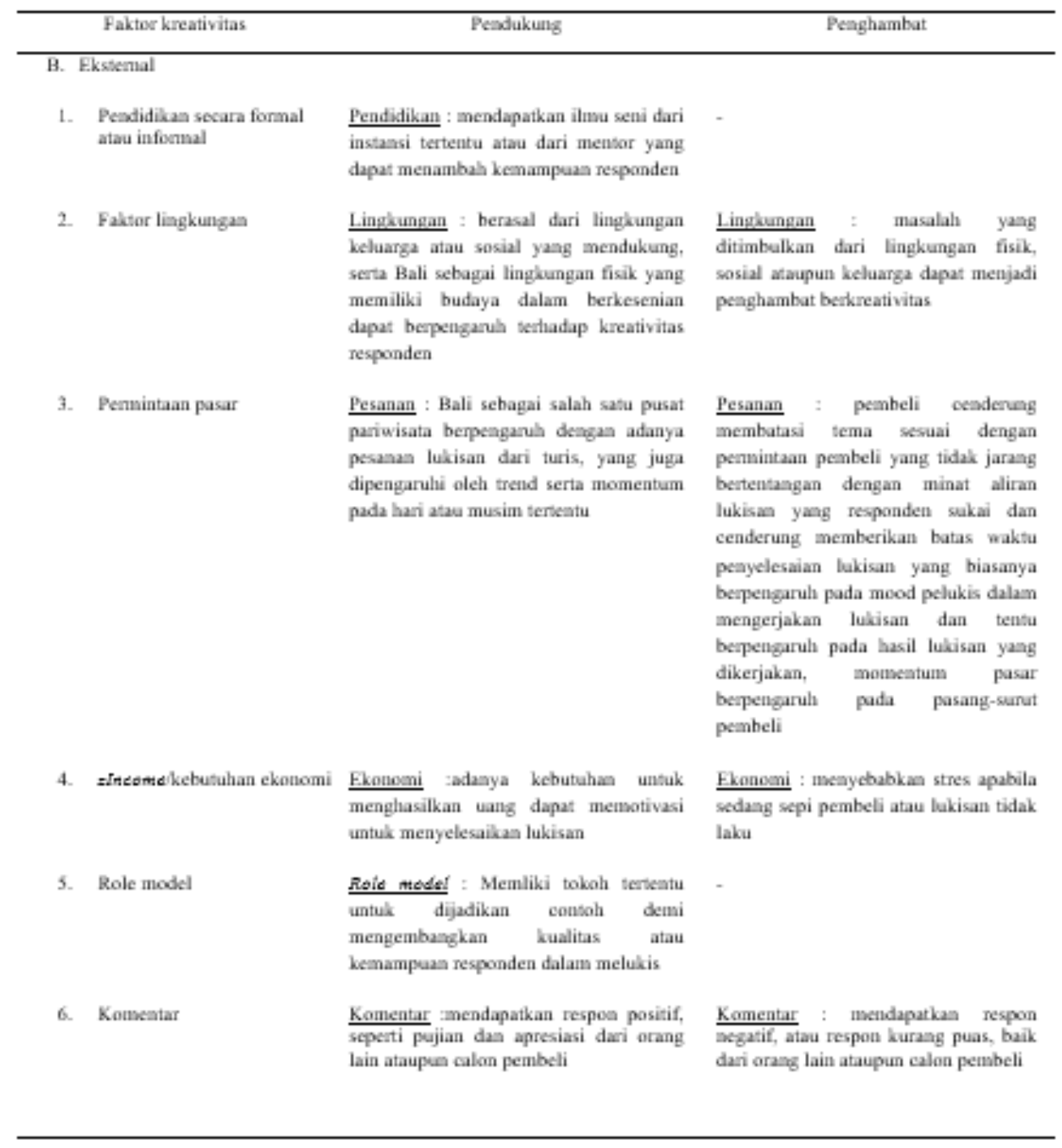




\section{Bagan 1}

Proses kreativitas pelukis

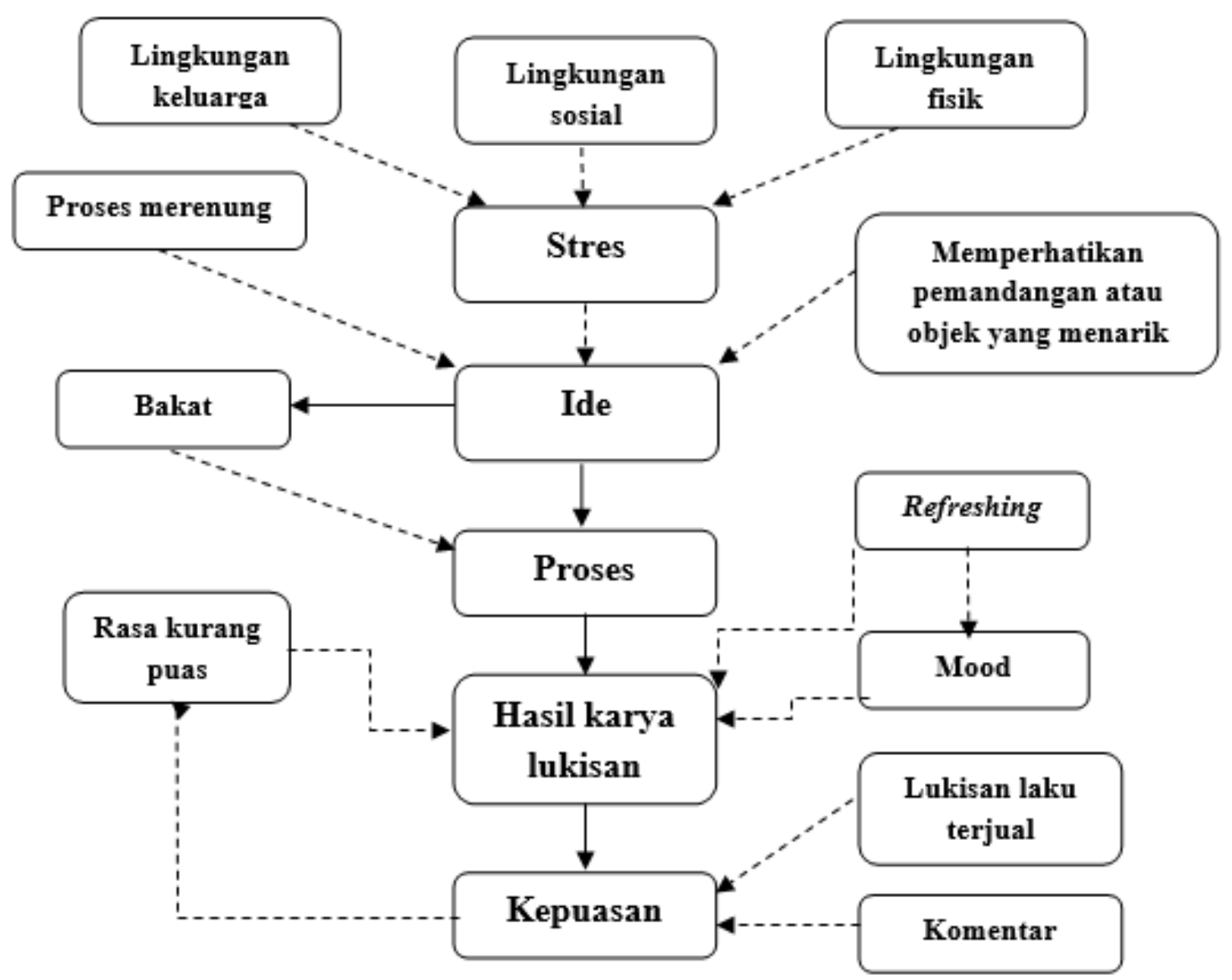




\section{Bagan 2.}

Pengaruh pariwisata Bali terhadap kreativitas pelukis

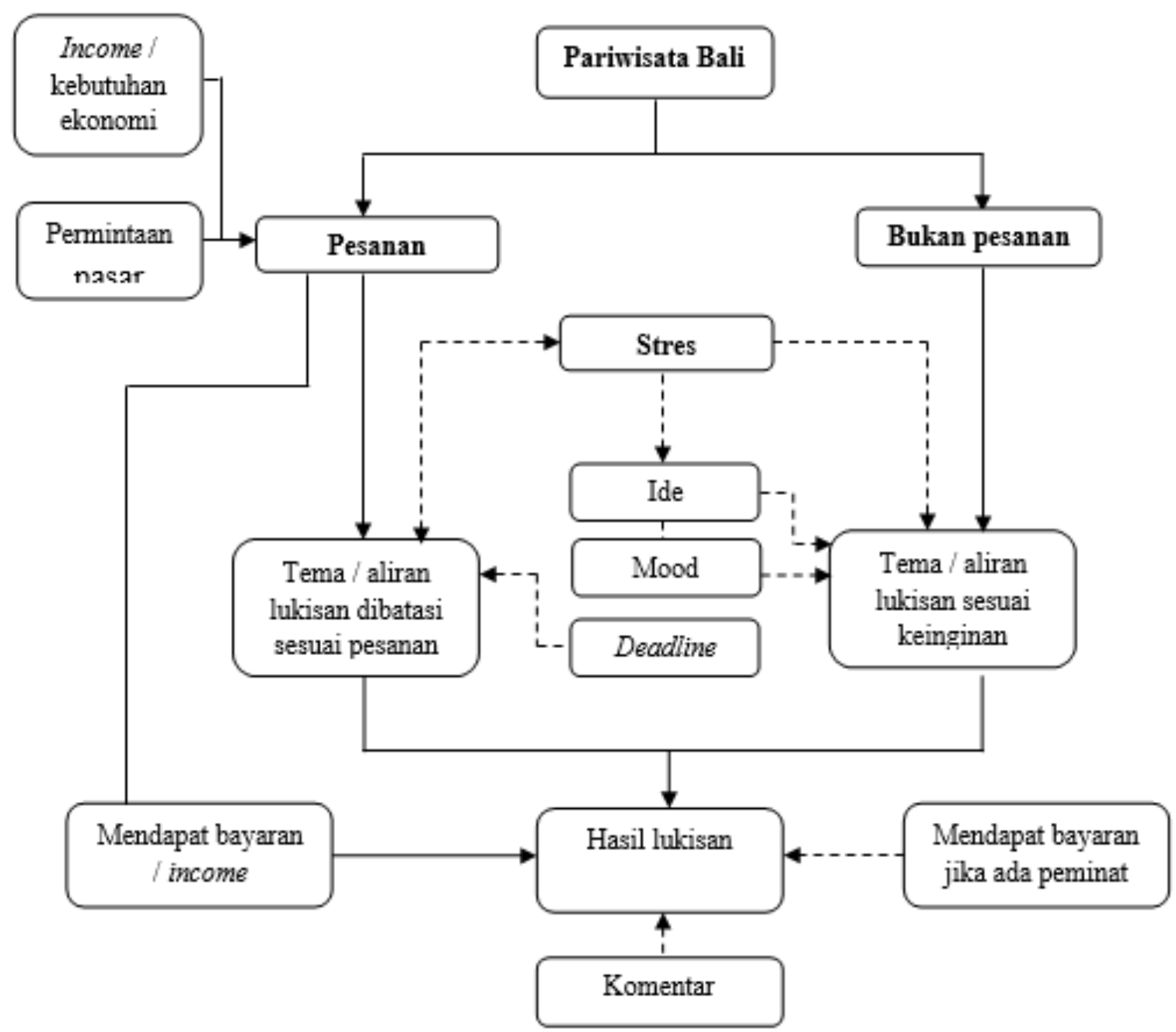

